\title{
ATRIBUT FISIK, KIMIA DAN SENSORIS MINUMAN JELI SUSU KERBAU
}

\section{Physical, Chemical and Sensory Attributes of Buffalo Milk Jelly Drinks}

\author{
Nura Malahayati", Friska Syaiful, Harumi Sujatmiko \\ Progam Studi Teknologi Hasil Pertanian, Jurusan Teknologi Pertanian \\ Universitas Sriwijaya, Inderalaya \\ Jl. Palembang-Prabumulih Km. 32 Indralaya, Ogan llir 30662 \\ *Penulis Korespondensi, Email: nura_malahayati@yahoo.com
}

\begin{abstract}
ABSTRAK
Penelitian ini bertujuan untuk menganalisis pengaruh komposisi karagenan, rasio susu dan air pada formulasi minuman jeli susu kerbau. Penelitian dilaksanakan di Laboratorium Kimia Hasil Pertanian, Universitas Sriwijaya. Rancangan Acak Lengkap dengan satu perlakuan yaitu komposisi karagenan dan rasio susu dan air adalah rancangan penelitian ini. Variabel penelitian yang diamati adalah tekstur, kadar air, kadar abu, protein, lemak, dan karbohidrat serta atribut sensoris meliputi aroma, rasa, dan tekstur. Hasil penelitian menunjukkan bahwa komposisi karagenan dan rasio susu dan air berpengaruh nyata terhadap nilai tekstur, kadar air, kadar abu, protein, lemak, dan karbohidrat, serta aroma, rasa, dan tekstur hasil dari uji sensoris. Minuman jeli susu kerbau dengan komposisi karagenan $(0.65 \%)$ dan rasio susu dan air $(60 \%: 40 \%)$ adalah perlakuan terbaik berdasarkan nilai tertinggi dari kandungan kadar abu $(0.78 \%)$, protein $(4.23 \%)$, dan skor tertinggi untuk penerimaan panelis terhadap rasa (3.40) dan tekstur (3.52).
\end{abstract}

Kata kunci: Karagenan, Minuman jeli, Susu kerbau

\section{ABSTRACT}

The objective of this research was to analyze the effect of carrageenan composition, the ratio of buffalo milk and water on physical, chemical and sensory attributes of buffalo milk jelly drinks formulation. The research was conducted at Agricultural Product Chemistry Laboratory, Sriwijaya University. Completely Randomized Design using one factor, composition of carrageenan and ratio of milk to water, was used in this research. Observed parameters were physical (texture), chemical (moisture, ash, protein, fat, and carbohydrate), and sensory (flavor, taste, and texture) attributes. Results indicated that the composition of carrageenan and ratio of milk to water had significant effect on physical, chemical, and sensory attributes. The buffalo milk jelly drink with composition of carrageenan $(0.65 \%)$ and ratio of milk to water $(60 \%: 40 \%)$ was the best treatment based on the highest content of ash $(0.78 \%)$, protein $(4.23 \%)$, and the highest score of panelists acceptance for taste (3.40) and texture (3.52).

Keywords: Buffalo milk, Carrageenan, Jelly drink

\section{PENDAHULUAN}

Indonesia memiliki kekayaan keanekaragaman hayati yang berlimpah, salah satunya adalah kerbau (Bulbalus bubalis). Kerbau termasuk ruminansia yang hidup hampir di seluruh wilayah Nusantara karena mempunyai kemampuan berkembang dalam agroekosistem yang luas.

Sumatera Selatan adalah salah satu daerah propinsi dengan jumlah penyebaran kerbau rawa yang besar di Indonesia di samping Sumatera Utara dan Kalimantan Selatan. Kerbau Pampangan merupakan kerbau rawa yang hidup di Kabupaten Ogan Komering llir 
(OKI), Provinsi Sumatera Selatan dimana hewan ini merupakan hasil perekonomian daerah selain padi dan palawija. Pemanfaatan kerbau rawa pampangan selain dagingnya adalah susu kerbau rawa yang dengan jumlah produksi sebesar 1-1.5 liter/ekor/hari (Damayanthi et al., 2014).

Kadar protein dan kadar lemak susu kerbau rawa berturut-turut sebesar $5.14 \pm 0.37 \%$ dan $7.23 \pm 1.58 \%$. Nilai ini lebih tinggi dibandingkan dengan kandungan protein dan lemak susu kerbau sungai yaitu sebesar $4.13 \pm 0.73 \%$ dan $4.68 \pm 0.41 \%$ (Pandey dan Voskuil, 2011). Selanjutnya, penelitian yang dilakukan oleh Hamad dan Baiomy (2010) melaporkan bahwa kandungan protein dan lemak, serta kandungan mineral susu kerbau rawa lebih baik jika dibandingkan dengan susu sapi. Susu kerbau juga kaya akan kandungan mineral penting, yaitu $\mathrm{Ca}, \mathrm{Fe}, \mathrm{P}$ dan kandungan vitamin A (Febrina, 2010).

Pemanfaatan susu kerbau di daerah Sumatera Selatan hanya sebatas susu segar dan produk pangan tradisional yaitu gulo puan dan sagon puan. Terbatasnya pilihan produk yang ada menjadikan rendahnya minat masyarakat terhadap susu kerbau. Faktor lain yang menyebabkan rendahnya pemanfaatan susu kerbau karena susu kerbau memiliki aroma serta rasa susu yang kurang diminati. Oleh karena itu perlu adanya upaya pengembangan produk olahan susu kerbau rawa agar dapat diterima oleh masyarakat terutama anak-anak.

Menurut Marini et al. (2016), minuman jeli merupakan salah satu produk minuman berbentuk gel yang terbuat dari senyawa hidrokoloid seperti karagenan yang ditambahkan dengan gula, asam, dan bahan tambahan pangan lain yang diperbolehkan. Salah satu produk pangan ringan yang banyak disukai oleh hampir semua kelompok umur adalah minuman jeli. Minuman jeli bisa dikatakan termasuk ke dalam jenis minuman yang dikonsumsi sebagai minuman pemberi energi (Agustin dan Putri, 2014). Hal ini mengingat saat ini produk minuman jeli yang banyak dipasarkan umumnya terbuat dari jus buah atau sayuran dan hanya mengutamakan kandungan serat pangan dan vitamin $\mathrm{C}$.

Kriteria minuman jeli yang baik adalah mudah hancur tetapi bentuk gelnya masih terasa di mulut saat dikonsumsi dengan menggunakan bantuan sedotan (Widawati dan Hardiyanto, 2016). Penambahan senyawa hidrokoloid diperlukan dalam pembentukan tekstur gel yang baik dan mudah dihisap pada produk minuman jeli. Karagenan adalah salah satu senyawa hidrokoloid yang biasa dipakai dalam pembuatan minuman jeli (Ardin dan Syahrumsyah, 2015). Pemilihan karagenan sebagai senyawa hidrokoloid karena struktur gel yang dibentuk oleh karagenan cenderung elastis dan kenyal (Sugiarso dam Nisa, 2015).

Karagenan adalah senyawa hasil ekstraksi rumput laut yang termasuk kelompok polisakarida galaktosa (Wati dan Saidi, 2015). Konsentrasi karagenan yang digunakan akan mempengaruhi kekokohan tekstur gel minuman jeli yang terbentuk. Selain itu, perbandingan penambahan susu dan air juga berpengaruh pada minuman jeli yang dihasilkan. Berdasarkan uraian di atas, penelitian ini akan mengkaji pengaruh komposisi karagenan, rasio susu dan air pada formulasi minuman jeli susu kerbau.

\section{BAHAN DAN METODE}

\section{Bahan}

Penelitian ini menggunakan bahan-bahan seperti air, gula, asam sitrat, kappa karagenan (Semi refine, Indonesia), dan susu kerbau dari Pampangan yang berasal dari Kabupaten Ogan Komering Ilir, Provinsi Sumatera Selatan.

\section{Alat}

Alat-alat yang digunakan dalam penelitian ini adalah alat-alat gelas, alat pasteurisasi (Indotrading, Indonesia), desikator, cawan porselen, cawan aluminium, hot plate (Barnstead Thermolyne, USA), muffle furnace (Barnstead Thermolyne, USA), oven (Memmert, Germany), neraca analitik (Adventure Ohaus, USA), refraktometer (Milwaukee, Romania), Soxhlet, dan Texture analyzer (Brookfield, CT3, Ametek inc, USA). 


\section{Desain Penelitian}

Tabel 1. Formulasi Pembuatan Minuman Jeli Susu Kerbau

\begin{tabular}{lcccccc}
\hline \multicolumn{1}{c}{ Bahan } & \multicolumn{7}{c}{ Formulasi } \\
\cline { 2 - 7 } & A & B & C & D & E & F \\
\hline Susu kerbau (v/v) & $40 \%$ & $50 \%$ & $60 \%$ & $40 \%$ & $50 \%$ & $60 \%$ \\
Air (v/v) & $60 \%$ & $50 \%$ & $40 \%$ & $60 \%$ & $50 \%$ & $60 \%$ \\
Kappa karagenan (b/v) & $0.55 \%$ & $0.55 \%$ & $0.55 \%$ & $0.65 \%$ & $0.65 \%$ & $0.65 \%$ \\
Gula (b/v) & $10 \%$ & $10 \%$ & $10 \%$ & $10 \%$ & $10 \%$ & $10 \%$ \\
Asam sitrat (b/v) & $0.15 \%$ & $0.15 \%$ & $0.15 \%$ & $0.15 \%$ & $0.15 \%$ & $0.15 \%$ \\
\hline
\end{tabular}

${ }^{\star}$ Formulasi dibuat dalam volume total minuman $100 \mathrm{~mL}$ (susu : air)

\section{Tahapan Penelitian}

\section{Pembuatan minuman jeli susu kerbau}

Pembuatan minuman jeli susu kerbau mengacu pada penelitian Rachmayati et al. (2017) yang dimodifikasi. Kappa karagenan sesuai perlakuan dicampur dengan gula (10\%) dan asam sitrat $(0.15 \%)$ lalu ditambahkan air matang sesuai dengan rasio susu : air dengan total susu dan air $100 \%$. Semua bahan dicampur hingga homogen selanjutnya dipanaskan dan diaduk hingga mencapai suhu $90^{\circ} \mathrm{C}$ selama 2 menit lalu didiamkan hingga suhu turun menjadi $65^{\circ} \mathrm{C}$. Selanjutnya, ditambahkan susu kerbau yang telah dipasteurisasi sambil terus diaduk sampai homogen. Larutan yang telah homogen dimasukkan ke dalam cup kemudian larutan didinginkan pada suhu ruang hingga membentuk gel.

\section{Prosedur Analisis}

Analisis minuman jeli susu kerbau berupa atribut fisik yaitu tekstur, dimana uji tekstur menggunakan alat texture analyzer (Brookfield CT3, Ametek inc, USA). Atribut kimia yaitu kadar air, kadar protein, kadar lemak, kadar abu dan kadar karbohidrat (by difference) dianalisis merujuk metode AOAC (2005). Metode uji hedonik dilakukan secara sensoris untuk penilaian rasa, aroma, dan tekstur minuman jeli susu kerbau Pampangan. Penilaian kesukaan dilakukan dengan memberikan nilai sebagai berikut: $1=$ sangat tidak suka, $2=$ tidak suka, 3 = suka dan 4 = sangat suka. Panelis dalam uji kesukaan berjumlah 30 orang (Pratama, 2011).

\section{Metode Penelitian}

Rancangan penelitian yang digunakan adalah Rancangan Acak Lengkap (RAL) dengan satu faktor perlakuan yaitu komposisi karagenan dan rasio susu dengan air. Setiap perlakuan dilakukan 3 kali pengulangan. Berikut ini adalah rincian perlakuan yang digunakan dalam penelitian ini:

$A=$ Minuman jeli karagenan 0,55\%; rasio susu dan air (40\%: $60 \%)$

$\mathrm{B}=$ Minuman jeli karagenan $0,55 \%$; rasio susu dan air (50\%: $50 \%)$

$\mathrm{C}=$ Minuman jeli karagenan $0,55 \%$; rasio susu dan air $(60 \%: 40 \%)$

$\mathrm{D}=$ Minuman jeli karagenan $0,65 \%$; rasio susu dan air (40\%:60\%)

$E=$ Minuman jeli karagenan $0,65 \%$; rasio susu dan air $(50 \%: 50 \%)$

$\mathrm{F}=$ Minuman jeli karagenan 0,65\%; rasio susu dan air (60\%: $40 \%)$

Data hasil penelitian selanjutnya dianalisis menggunakan analisis keragaman (ANOVA) digunakan, jika terdapat perlakuan yang berpengaruh nyata maka dilanjutkan dengan uji Beda Nyata Jujur (BNJ) taraf 5\%. 


\section{HASIL DAN PEMBAHASAN}

\section{Atribut kimia susu kerbau rawa}

Atribut kimia susu kerbau rawa dan kappa karagenan disajikan pada Tabel 2.

Tabel 2. Atribut Kimia Susu Kerbau Rawa dan Kappa Karagenan

\begin{tabular}{lcc}
\hline Atribut Kimia (\%) & Susu Kerbau Rawa & Kappa Karagenan \\
\hline Kadar Air & $83.99 \pm 0.28$ & $11.60 \pm 0.27$ \\
Kadar Abu & $0.67 \pm 0.04$ & $21.22 \pm 0.59$ \\
Protein & $4.56 \pm 0.07$ & $1.99 \pm 0.10$ \\
Lemak & $10.16 \pm 0.08$ & $1.80 \pm 0.22$ \\
Karbohidrat & $0.61 \pm 0.17$ & $63.39 \pm 0.89$ \\
\hline
\end{tabular}

Keterangan : Nilai adalah rata-rata \pm SD

\section{Tekstur Minuman Jeli Susu Kerbau}

Rerata nilai tekstur minuman jeli susu kerbau berkisar antara 215.27 gf hingga 531.87 gf. Nilai yang terendah dihasilkan oleh perlakuan A sedangkan nilai tertinggi dihasilkan oleh perlakuan F. Hasil pengukuran rerata nilai tekstur minuman jeli susu kerbau tertera pada Gambar 1.

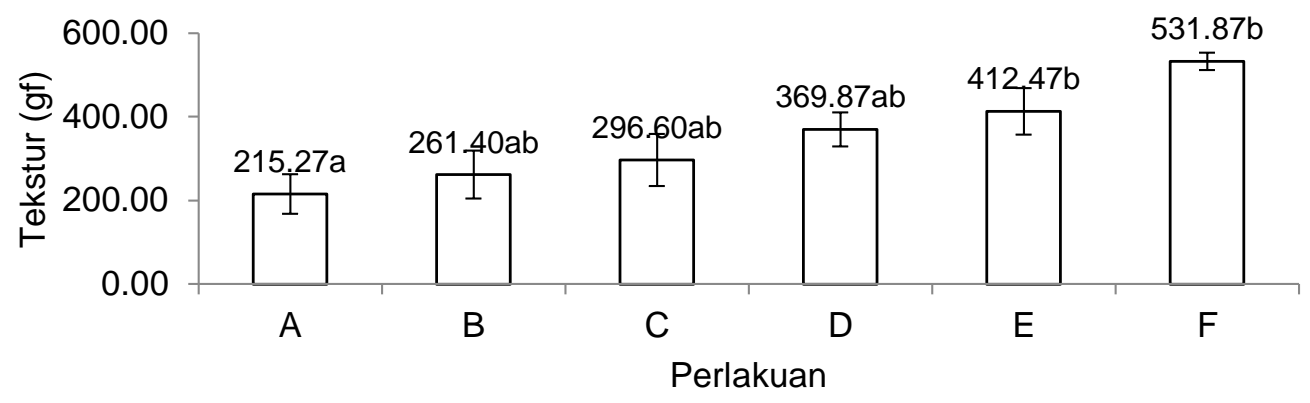

Gambar 1. Rerata Nilai Tekstur Minuman Jeli Susu Kerbau

Deretan angka pada histogram yang diikuti oleh huruf yang sama berarti tidak berbeda nyata pada $\mathrm{P}<0.05$

Analisis tekstur pada Gambar 1 menunjukkan bahwa nilai tekstur minuman jeli susu kerbau dipengaruhi oleh komposisi karagenan dan rasio susu kerbau dan air. Hasil nilai tekstur menunjukkan pengaruh nyata $(P<0.05)$ pada peningkatan nilai tekstur minuman jeli susu kerbau. Karagenan sebagai bahan pembentuk gel dapat meningkatan tekstur. Hal ini disebabkan peningkatan konsentrasi karagenan akan menyebabkan matriks yang terbentuk oleh rantai polimer double helix semakin banyak dan membentuk gel yang lebih kuat yang selanjutnya akan menjadikan tekstur minuman jeli susu kerbau bersifat kokoh. Hasil penelitian ini sejalan dengan hasil riset Vania et al. (2017) yang melaporkan bahwa peningkatan konsentrasi karagenan pada jelly drink papaya akan meningkatkan jumlah air yang terikat sehingga meningkatkan kekuatan gel.

Selain konsentrasi karagenan, penambahan susu kerbau juga mempengaruhi tekstur minuman jeli susu kerbau. Susu kerbau memiliki padatan yang cukup tinggi yaitu sebesar 16\% (Matondang dan Talib, 2015). Menurut Shaker et al. (2000), semakin banyak jumlah padatan, maka tekstur suatu produk akan semakin keras. Selanjutnya, Sunarlim et al. (2007) menyatakan produk yang mengandung bahan padat tinggi akan mengalami penurunan kadar air yang menyebabkan meningkatnya nilai tekstur.

Adanya reaksi antara protein susu kerbau dengan karagenan akan meningkatkan tekstur minuman jeli susu kerbau. Hal tersebut sesuai dengan pernyataan Winarno (1996) dalam Winarti et al. (2018), interaksi antara muatan negatif senyawa karagenan dengan 
muatan positif dari protein mampu menghasilkan peningkatan kekuatan gel akibat terbentuknya ikatan protein karagenat. Reaksi antara protein susu dengan karagenan dikenal sebagai "milk reactivity".

\section{Kadar Air Minuman Jeli Susu Kerbau}

Minuman jeli susu kerbau memiliki rerata nilai kadar air yang berkisar antara $77.63 \%$ hingga $80.71 \%$. Berdasarkan hasil analisis nilai terendah didapat oleh perlakuan $\mathrm{F}$ dan nilai tertinggi didapat oleh perlakuan A. Hasil pengujian rerata nilai kadar air minuman jeli susu kerbau tertera pada Gambar 2.

Gambar 2 memperlihatkan komposisi karagenan dan rasio susu kerbau dan air memiliki pengaruh nyata $(P<0.05)$ pada penurunan kadar air minuman jeli susu kerbau. Nilai kadar air minuman jeli susu dipengaruhi oleh karagenan. Menurut Widjaja et al. (2017), semakin tinggi konsentrasi karagenan akan mengakibatkan kadar air minuman jeli menurun. Struktur yang kuat dan kaku dalam bahan makanan terbentuk dengan penambahan karagenan yang bersifat sebagai pemantap, penstabil, dan pengental yang dapat mengimobilisasi air. Karagenan sebagai hidrokoloid bersifat hidrofilik dan tersusun dari senyawa D-galaktosa-4-sulfat dan 3,6-anhidro-D-galaktosa (Herawati, 2018). Sifat hidrofilik karagenan dipengaruhi oleh gugus ester sulfat dan gugus galaktosa yang menyusun karagenan (Imerson, 2000). Penambahan konsentrasi karagenan yang semakin tinggi pada produk bahan akan menurunkan kadar air dalam bahan tersebut.

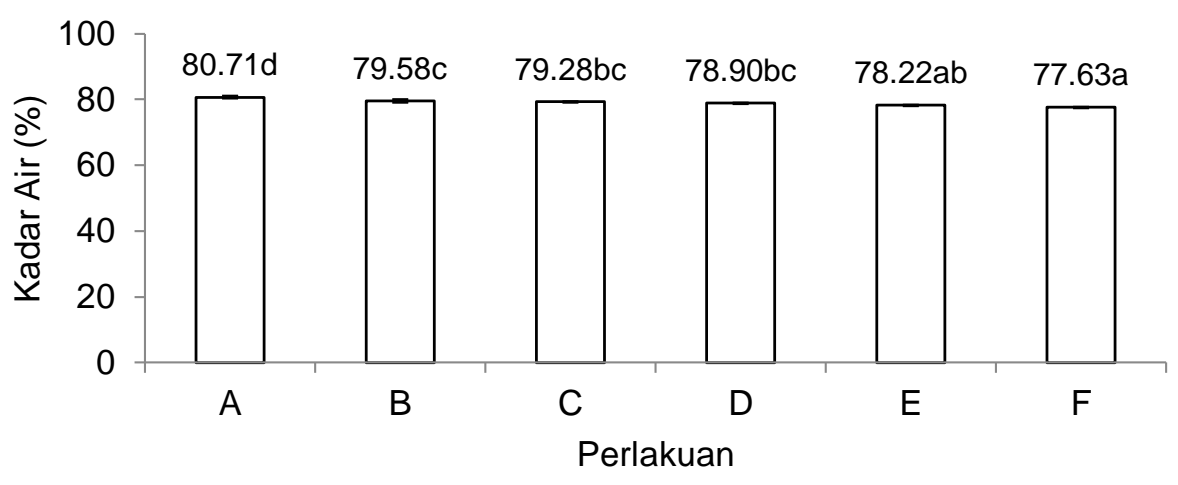

Gambar 2. Rerata Nilai Kadar Air Minuman Jeli Susu Kerbau

Deretan angka pada histogram yang diikuti oleh huruf yang sama berarti tidak berbeda nyata pada $\mathrm{P}<0.05$

\section{Kadar Abu Minuman Jeli Susu Kerbau}

Rerata nilai kadar abu minuman jeli susu kerbau berkisar antara $0.71 \%$ hingga $0.78 \%$. Perlakuan A memilliki nilai terendah sedangkan perlakuan $F$ memiliki nilai tertinggi. Hasil pengukuran rerata nilai kadar abu minuman jeli susu kerbau tertera pada Gambar 3. 


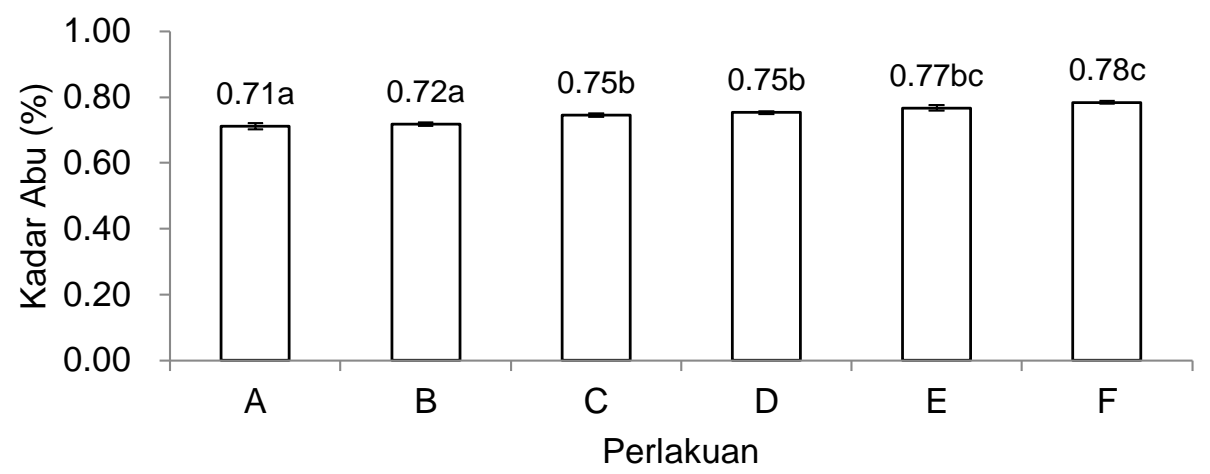

Gambar 3. Rerata Nilai Kadar Abu Minuman Jeli Susu Kerbau

Deretan angka pada histogram yang diikuti oleh huruf yang sama berarti tidak berbeda nyata pada $\mathrm{P}<0.05$

Hasil analisis keragaman menunjukkan bahwa komposisi karagenan dan rasio susu kerbau dan air memilki pengaruh nyata $(P<0.05)$ pada peningkatan nilai kadar abu minuman jeli susu kerbau. Peningkatan kadar abu disebabkan kandungan mineral yang terdapat pada susu kerbau. Sumber utama kadar abu minuman jeli susu kerbau berasal dari susu kerbau Pampangan yang digunakan dalam penelitian ini. Susu kerbau Pampangan mengandung kadar abu sebesar $0.67 \pm 0.04 \%$ (Tabel 2). Susu kerbau mengandung kalsium $163.19 \mathrm{mg}$, fosfor $111.36 \mathrm{mg}$, zat besi $0.135 \mathrm{mg}$, seng $0.24 \mathrm{mg}$, natrium $51.61 \mathrm{mg}$, kalium $167.18 \mathrm{mg}$, magnesium $29.56 \mathrm{mg}$, tembaga $0.04 \mathrm{mg}$, dan mangan $0.02 \mathrm{mg}$ (Soliman, 2005).

Selain itu, minuman jeli susu kerbau juga mengandung mineral yang dikontribusikan oleh karagenan. Berdasarkan FAO dan EEC, kadar abu karagenan berkisar antara 15-24\% dan FCC menetapkan kadar abu maksimal karagenan adalah 35\%. Sukri (2006) menyatakan rumput laut mengandung mineral $\mathrm{Na}, \mathrm{K}, \mathrm{Cl}, \mathrm{Ca}, \mathrm{Mg}, \mathrm{Fe}, \mathrm{S}$, dan I yang cukup tinggi dan digunakan sebagai bahan utama karagenan.

\section{Kadar Protein Minuman Jeli Susu Kerbau}

Rerata nilai kadar protein minuman jeli susu kerbau berkisar antara $3.62 \%$ hingga 4.23\%. Nilai terendah diperoleh perlakuan A dan nilai tertinggi diperoleh perlakuan F. Hasil pengukuran rerata nilai kadar protein minuman jeli susu kerbau tertera pada Gambar 4.

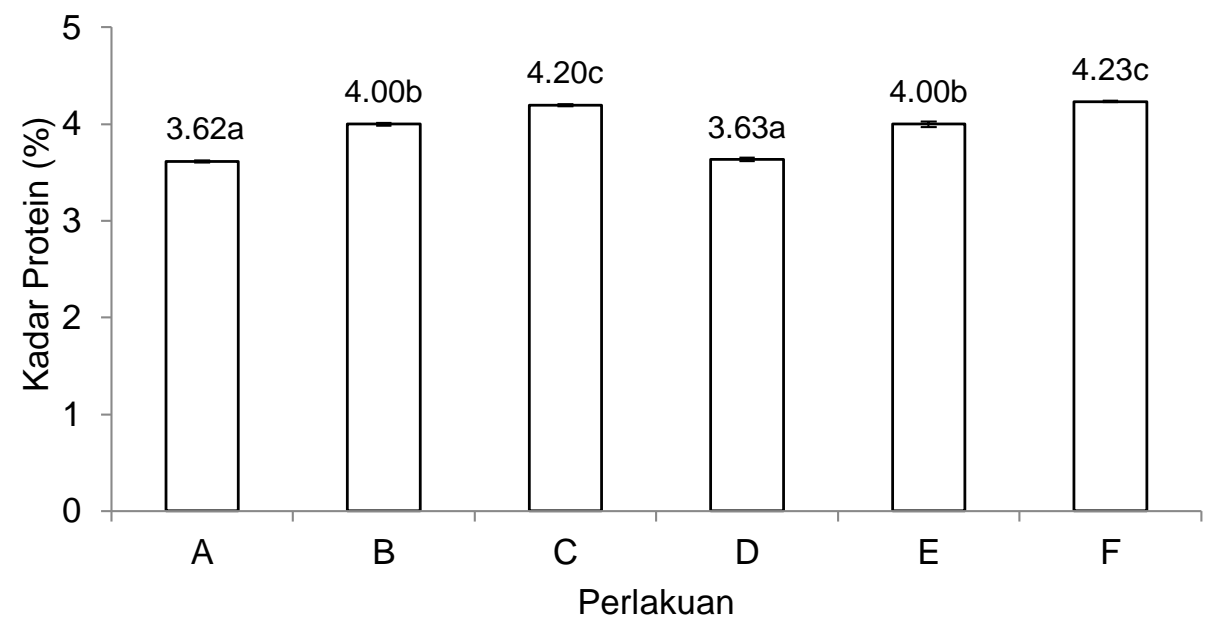

Gambar4. Rerata Nilai Kadar Protein Minuman Jeli Susu Kerbau 
Deretan angka pada histogram yang diikuti oleh huruf yang sama berarti tidak berbeda nyata pada $\mathrm{P}<0.05$

Komposisi karagenan dan susu kerbau memberikan pengaruh nyata $(P<0.05)$ pada kadar protein minuman jeli susu kerbau berdasarkan hasil analisis keragaman. Gambar 4 menunjukkan komposisi karagenan $0.55 \%$ atau $0.65 \%$, rasio susu dan air $50 \%$ : $50 \%$ dapat meningkatkan nilai kadar protein minuman jeli susu kerbau secara signifikan. Peningkatan kadar protein disebabkan penambahan susu kerbau Pampangan yang merupakan sumber utama protein. Susu kerbau mengandung protein sebesar $4.56 \pm 0.07 \%$ (Tabel 2).

\section{Kadar Lemak Minuman Jeli Susu Kerbau}

Rerata nilai kadar lemak minuman jeli susu kerbau yaitu antara 5.47\% hingga $9.65 \%$. Nilai terendah diperoleh perlakuan $A$ dan nilai tertinggi diperoleh perlakuan $F$. Hasil pengukuran rerata nilai kadar lemak minuman jeli susu kerbau tertera pada Gambar 5.

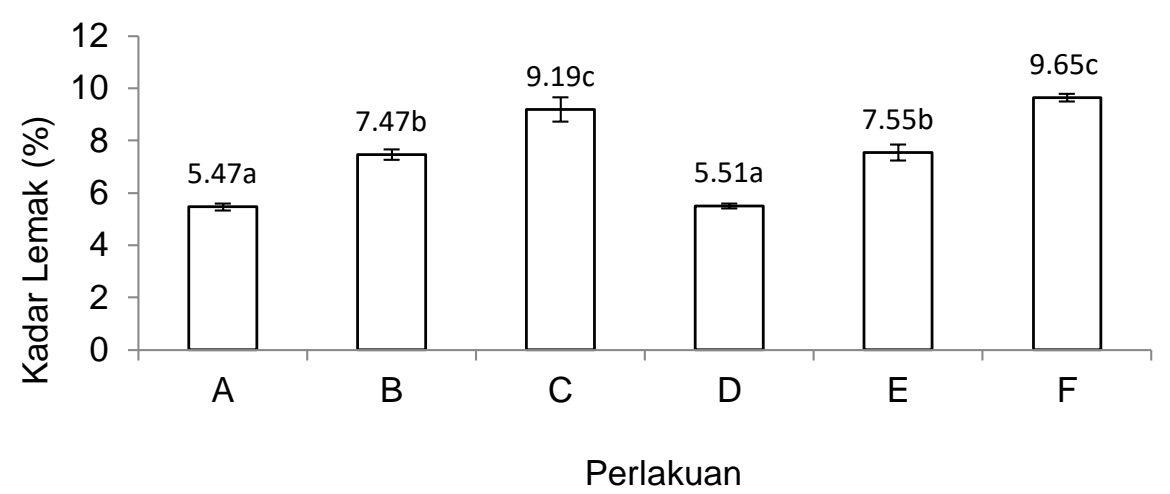

Gambar 5. Rerata Nilai Kadar Lemak Minuman Jeli Susu Kerbau

Deretan angka pada histogram yang diikuti oleh huruf yang sama berarti tidak berbeda nyata pada $\mathrm{P}<0.05$

Komposisi karagenan dan susu kerbau berpengaruh nyata $(P<0.05)$ terhadap nilai lemak minuman jeli susu kerbau berdasarkan hasil analisis keragaman. Gambar 5 menunjukkan komposisi karagenan $0.55 \%$ atau $0.65 \%$, rasio susu dan air $50 \%$ : $50 \%$ dapat meningkatkan nilai kadar protein minuman jeli susu kerbau secara signifikan. Peningkatan kadar lemak disebabkan penambahan susu kerbau Pampangan yang merupakan sumber utama lemak. Susu kerbau mengandung lemak sebesar $10.16 \pm 0.01 \%$ (Tabel 2).

\section{Atribut Sensoris Minuman Jeli Susu Kerbau}

Pada penelitian ini atribut sensoris hedonik yang diamati adalah aroma, rasa dan tekstur. Hasil uji sensoris hedonik rerata minuman jeli susu kerbau tertera pada Tabel 3. Nilai penerimaan panelis terhadap aroma minuman jeli susu kerbau cenderung menurun dengan meningkatnya konsentrasi penambahan susu kerbau rawa. Hal ini karena susu kerbau rawa memiliki aroma yang khas sehingga penambahan konsentrasi susu kerbau akan meningkatkan aroma khas susu pada minuman jeli. Aroma khas susu ini tidak bisa diterima sebagian besar panelis. Menurut Sari et al. (2014), aroma khas susu kerbau berasal dari asam lemak volatil yang terdapat dalam susu. Bau khas susu kerbau yang tidak disukai panelis berasal dari pengaruh asam lemak yaitu asam butirat, kaproat, kaplirat, kaprat, dan laurat. 
Atribut Fisik Kimia dan Sensoris Minuman Jeli Susu Kerbau - Malahayati, dkk Jurnal Pangan dan Agroindustri Vol.8 No.1: 19-28, Januari 2020

Tabel 3. Nilai Atribut Sensoris Hedonik Minuman Jeli Susu Kerbau

\begin{tabular}{cccc}
\hline \multirow{2}{*}{ Perlakuan } & \multicolumn{3}{c}{ Karakteristik Sensoris Hedonik } \\
\cline { 2 - 4 } & Aroma & Rasa & Tekstur \\
\hline A & $2.88^{\mathrm{b}}$ & $2.60^{\mathrm{ab}}$ & $2.04^{\mathrm{a}}$ \\
B & $2.76^{\mathrm{ab}}$ & $2.84^{\mathrm{bc}}$ & $2.24^{\mathrm{ab}}$ \\
C & $2.68^{\mathrm{a}}$ & $3.20^{\mathrm{cd}}$ & $2.60^{\mathrm{b}}$ \\
D & $3.24^{\mathrm{c}}$ & $2.44^{\mathrm{a}}$ & $3.04^{\mathrm{c}}$ \\
E & $3.12^{\mathrm{bc}}$ & $2.96^{\mathrm{bc}}$ & $3.28^{\mathrm{cd}}$ \\
F & $2.92^{\mathrm{b}}$ & $3.40^{\mathrm{d}}$ & $3.52^{\mathrm{d}}$
\end{tabular}

Keterangan : Angka-angka yang diikuti huruf yang sama pada kolom yang sama berarti tidak berbeda nyata pada $\mathrm{P}<0.05$

Nilai penilaian panelis terhadap aroma minuman jeli susu kerbau berbanding terbalik dengan penambahan konsentrasi karagenan. Peningkatan konsentrasi karagenan yang ditambahkan akan meningkatkan kesukaan panelis terhadap aroma minuman jeli susu kerbau. Pemanasan saat proses pembuatan minuman jeli menyebabkan terjadi pengikatan komponen volatil oleh karagenan sehingga menyebabkan aroma menurun (Ekafitri et al., 2016). Semakin tinggi karagenan maka semakin tinggi komponen volatil yang terikat, menyebabkan semakin sedikit aroma khas susu yang tercium.

Nilai penerimaan panelis terhadap rasa minuman jeli susu kerbau cenderung meningkat dengan semakin banyaknya konsentrasi susu yang diberikan. Peningkatan ini karena semakin banyak susu yang ditambahkan menyebabkan rasa minuman jeli susu kerbau menjadi lebih gurih dan terasa manis. Rasa yang ada pada minuman jeli susu kerbau dipengaruhi oleh rasa dari susu kerbau. Kandungan lemak pada susu kerbau memberikan rasa gurih dan laktosa susu menyebabkan susu terasa manis (Suhendra et al., 2015).

Adanya penurunan penilaian panelis terhadap rasa minuman jeli susu kerbau karena peningkatan konsentrasi air yang ditambahkan pada minuman jeli susu. Menurut Palupi et al. (2007), semakin banyak penambahan air akan menurunkan kandungan kimia bahan tersebut. Oleh sebab itu, panelis lebih menyukai perlakuan $\mathrm{F}$ (karagenan $0.65 \%$; $40 \%$ air : $60 \%$ susu kerbau) karena rasa yang dihasilkan lebih gurih dan manis.

Nilai penerimaan panelis terhadap tekstur minuman jeli susu kerbau cenderung meningkat dengan semakin banyaknya konsentrasi karagenan dan susu yang diberikan. Pada pembuatan produk makanan, bahan yang digunakan sebagai pembentuk gel adalah karagenan (Restiana et al., 2014). Konsentrasi karagenan yang ditambahkan semakin tinggi maka semakin banyak gugus hidroksil yang digunakan untuk membentuk gel. Selanjutnya, gugus hidroksil ini akan membentuk struktur double helix dengan jumlah yang banyak dan kuat. Oleh karena itu, minuman jeli dengan konsentrasi karagenan yang lebih banyak dapat mempertahankan bentuknya sebagai gel.

Menurut Widawati dan Hardiyanto (2016), kriteria minuman jeli yang baik adalah memiliki tekstur mantap (firm), mudah hancur ketika diminum dengan sedotan, dan dimulut masih terasa bentuk gelnya. Oleh sebab itu, panelis lebih menyukai perlakuan $\mathrm{F}$ (karagenan $0.65 \%$ dan $40 \%$ air : $60 \%$ susu kerbau) karena pada konsentrasi tersebut panelis mendapatkan tekstur yang diinginkan yaitu tekstur tidak keras tetapi juga tidak lunak sehingga mudah untuk disedot. Hal ini karena penambahan air yang lebih sedikit $(40 \%$ air: $60 \%$ susu kerbau) dan pada konsentrasi karagenan $0.65 \%$ mampu membentuk gel yang lebih kuat membuat tekstur minuman jeli lebih kokoh.

\section{SIMPULAN}

Penambahan konsentrasi karagenan dan rasio susu dengan air pada proporsi berbeda pada minuman jeli susu kerbau dapat meningkatkan tekstur, kadar protein, kadar abu dan kadar lemak, serta sensoris untuk rasa dan tekstur secara nyata tetapi menurunkan 
karakteristik kadar air, dan sensoris untuk aroma secara nyata. Minuman jeli susu kerbau dengan formulasi karagenan $0.65 \%$; rasio susu dan air (60\%: $40 \%)$ merupakan perlakuan terbaik berdasarkan nilai tertinggi dari kandungan kadar abu dan protein, serta menghasilkan tekstur dan rasa yang sangat disukai panelis.

\section{UCAPAN TERIMA KASIH}

Penulis berterima kasih sebesar-besarnya kepada Badan Restorasi Gambut (BRG) yang telah mendanai dan telah membimbingdalam pelaksanaan penelitian ini.

\section{DAFTAR PUSTAKA}

Agustin, F., dan Putri, W. D. R. 2014. Pembuatan jelly drink Averrhoablimbi L. (kajian proporsi belimbing wuluh : air dan konsentrasi karagenan). Jurnal Pangan dan Agroindustri, 2(3), 1 - 9 .

AOAC. 2005. Official Methods of Analysis. Association of Official Analytical Chemistry. Washington DC. United State of America.

Ardin, B. G. H., dan Syahrumsyah, H. 2015. Pengaruh karagenan terhadap sifat kimia dan sensoris minuman jeli sari buah nanas (Ananascomosus L. Merr). Jurnal Teknologi Pertanian Universitas Mulawarman, 10(1), 18-22.

Damayanthi, E., Hasinah, H., Setyawardani, T., Rizqiati, H., dan Putra, S. 2014. Karakteristik susu kerbau sungai dan rawa di Sumatera Utara. Jurnal IImu Pertanian Indonesia, 19(2), $67-73$.

Ekafitri, R., Kumalasari, R., dan Desnilasari, D. 2016. Pengaruh jenis dan konsentrasi hidrokoloid terhadap mutu minuman jeli mix pepaya (Carica papaya) dan nanas (Ananascomosus). Jurnal Penelitian Pascapanen Pertanian, 13(3), 115-124.

Fardiaz, D. 1989. Hidrokoloid. Bogor : IPB.

Febrina, L. 2010. Analisis Usaha Ternak Kerbau pada Ketinggian Tempat yang Berbeda di Provinsi Sumatera Barat, Tesis. Universitas Andalas.

Firdiansyah. 2004. Pengaruh Konsentrasi Lesitin Kedelai dan Suhu Penyimpanan terhadap Stabilitas Emulsi Susu Kedelai, Tesis. Institut Pertanian Bogor.

Gomez, K. A. dan Gomez, A. A. 1995. Prosedur Statistik untuk Penelitian Pertanian. Edisi Kedua. Jakarta: UI Press.

Hamad, M. N. E., dan Baiomy, A. A. 2010. Physical properties and chemical composition of cow's and buffalo's milk in Qena governorate. Journal Food and Dairy Science, 1(7), 397-403.

Herawati, H. 2018. Potensi hidrokoloid sebagai bahan tambahan pada produk pangan dan nonpangan bermutu. Jurnal Litbang Pertanian, 37(1), 17-25.

Imerson, A.P. 2000. Handbook of Hydrocolloids, UK: FMC Corporation Ltd [https://www.cabdirect.org/cabdirect/20013119633] [Diakses pada 26 Januari 2019].

Kusnandar, F. 2011. Kimia PanganKomponen Makro. Jakarta : Penerbiat Dian Rakyat.

Marini, S. M., Desniar, dan Santoso, J. 2016. Karakteristik minuman jelly probiotik dengan penambahan Lactobacillus plantarum (SK5) asal bekasam selama penyimpanan. JPHPI, 19(3), 288-298.

Matondang, R. H., dan Talib, C. 2015. Pemanfaatan ternak kerbau untuk mendukung peningkatan produksi susu. Jurnal Litbang Pertanian, 34(1), 41 - 49.

Palupi, N. S., Zakaria, F. R., dan Prangdimurti, E. 2007. Pengaruh Pengolahan terhadap Nilai Gizi Pangan. Bogor : IPB.

Pandey, G. S., dan Voskuil, G. C. J. 2011. Manual on Milk Safety. Zambia : Golden Valley Agricultural Research Trust.

Picauly, P., Talahatu, J., dan Mailoa, M. 2015. Pengaruh penambahan air pada pengolahan susu kedelai. Jurnal Teknologi Pertanian, 4(1), 8-13. 
Rachmayati, H., Wahono, H.S. dan Jaya, M.M., 2017. Pengaruh tingkat kematangan buah belimbing (Averrhoa carambola L.) dan proporsi penambahan gula terhadap karakteristikfisik, kimia dan organoleptik jelly drink mengandung karaginan. Jurnal Pangan dan Agroindustri, 5(1), 49-60.

Restiana, N. I., Wignyanto, dan Febrianto, A. 2014. Pembuatan jelly drink filtrate kulit pisang Candi (Musa acuminata) (kajian penambahan konsentrasi karagenan dan agar-agar). Jurnal Pangan dan Agroindustri, 3(2), 11-19.

Sari, N. A., Sustiyah, A. dan Legowo, A. M. 2014. Total bahan padat, kadar protein, dan nilai kesukaan keju mozzarella dari kombinasi susu kerbau dan susu sapi. Jurnal Aplikasi Teknologi Pangan, 3(4).

Shaker, R. R., Jumah, R. Y., dan Abu-jdayil, B.2000. Reological properties of plain yogurt during coagulation process: impact of fat content and preheat treatment milk. J. Food Eng., 44, 175-180.

Sitorus, A., dan Anggreani, A. 2008. Karakterisasi morfologi dan estimasi jarak genetic kerbau rawa, sungai (Murrah) dan silangannya di Sumatera Utara. Seminar dan Lokakarya Nasional Usaha Ternak Kerbau.

Soliman, G. Z. A. 2005. Comparison of chemical and mineral content of milk from human, cow, buffalo, camel and goat in egypt. The Egyptian Journal of Hospital Medicine, 21(1), 116-130.

Standar Nasional Indonesia. 1992. Cara Uji Makanan dan Minuman. Jakarta: Standar Nasional Indonesia.

Sugiarso, A., dan Nisa, F. C. 2015. Pembuatan minuman jeli Murbei (Morus alba L.) dengan pemanfaatan tepung Porang ( $A$. muelleri Blume) sebagai subtitusi karagenan. Jurnal Pangan dan Agroindusri, 3(2), 443-452.

Suhendra, D., Anggiati, G. T., Sarah, S., Nasrullah, A. F., Thimoty, A., dan Utama, D. 2015. Tampilan kualitas susu sapi perah akibat imbingan konsentrat dan hijauan yang berbeda. Jurnal Ilmu-ilmu Peternakan, 25(1), 42-46.

Sukri, N. 2006. Karakteristik Alkali Treated Cottonii (ATC) dan Karagenan dari Rumput Laut Eucheuma cottonii pada Umur Panen yang Berbeda, Tesis. Institute Pertanian Bogor.

Sunarlim, R., Setoyanto, H., dan Poeloengan, M. 2007. Pengaruh kombinasi starter bakteri Lactobacillus bulgaricus, Streptococcus thermophillus, dan Lactobacillus plantarum terhadap sifat mutu susu fermentasi. Seminar Nasional Teknologi Peternakan dan Veteriner. 7(07), 270-278.

Vania, J., Utomo, A. R., dan Trisnawati, C. Y. 2017. Pengaruh perbedaan konsentrasi karagenan terhadap karakteristik fisiko kimia dan organoleptik jelly drink pepaya. Jurnal Teknologi Pangan dan Gizi, 16(1), 8-13.

Wati, I., dan Saidi, A. 2015. Penggunaan rumput laut (Eucheumacottonii) sebagai pengganti karagenan dalam pembuatan jelly drink rosella (kajian konsentrasi rumput laut dan karagenan). Jurnal Nabatia, 12(1), $43-50$.

Widawati, L., dan Hardiyanto, H. 2016. Pengaruh konsentrasi karagenan terhadap sifat fisik, kimia dan organoleptik minuman jeli nanas (Ananascomosus L. Merr). Jurnal IImu dan Teknologi Pertanian, 2(2), 144-153.

Widjaja, W. P., Sumartini, dan Rifani. 2017. Pengaruh konsentrasi jelly power terhadap karakteristik minuman jeli ikan lele (Clarias sp.). Pasundan Food Technology Journal, 4(3), $197-207$.

Winarti, S., Sarofah, U., dan Rodiyah, K. F. 2018. Karakteristik jelly drinks inbiotik dari susu kedelai dan ekstrak buah naga merah (Hylocereuspolyrhizus). Jurnal Agrointek, 12(1), $61-73$. 